\title{
INVESTIGATION OF THE OPERATION OF VIBRATION- CENTRRIFUGAL INSTALLATION FOR AUTOMOBILE PARTS MACHINING
}

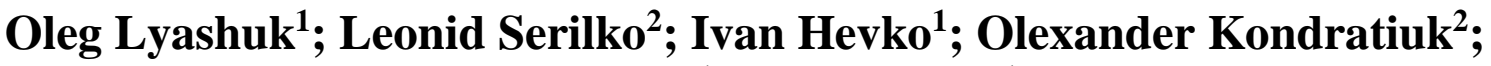 \\ Oleg Tsion'; Yuriy Galan ${ }^{1}$
}

\author{
${ }^{1}$ Ternopil Ivan Puluj National Technical University, Ternopil, Ukraine \\ ${ }^{2}$ National University of Water and Environmental Engineering, Rivne, Ukraine
}

Summary. The scheme of vibration-centrifugal installation, providing the increase of productivity and efficiency of machine parts vibration treatment is presented in this paper. The influence of the treated environment on the technological vibration treatment process and determination of its optimal parameters is investigated on the basis of mathematical modeling. Graphical dependences of specific kinetic energy on the crank rotational velocity at different values of the fork rotational velocity are presented. Effective ways of technological process parameters optimization and new ways of its development are identified.

Key words: vibration treatment, technological process, abrasive granule, granule speed, kinetic energy.

Statement of the problem. High-performance methods of machine parts cleaning, grinding and hardening are of great importance for ensuring the quality of mechanical engineering products. Their application engages the intensification of various finishing methods, which with a sharp increase in the volume of cleaning, grinding, polishing and hardening operations account for $10 \ldots 20 \%$ of the total labor intensity of machine parts manufacturing.

While developing and implementing a new high-performance finishing, the vibration treatment method for machine parts with complex shape in loose abrasive medium is used. Numerous varieties of this method require intensive study and investigation.

Analysis of available investigations and publications. Improvement of the productivity and efficiency of machine parts vibration treatment in loose abrasive medium creates the preconditions for the new ways of its development [1-2,4]. One of the most intensive methods of this technological process is vibration-centrifugal treatment of machine parts in the installations with the rigid kinematic scheme which create compound motion of the working environment within the chamber. Vibration-centrifugal treatment can be carried out not only in the installations with spatial or planetary motion of the working chamber, but also in the installations with working chamber movement along the complex spatial curve. The vibration-centrifugal unit, the working chamber of which is located in the middle of cardan suspension and performs complex angular oscillations deserves consideration. This technological process of machine parts vibration treatment in loose abrasive medium increases its intensity by $2 \ldots 2.5$ times [6-9]. In such a case, the problem of technological process improvement requires further investigations and testing. 
The objective of the paper is to investigate the vibration-centrifugal treatment of machine parts in loose abrasive medium using mathematical modeling of the technological process and to determine its optimal parameters.

Implementation of work. The scheme of vibration-centrifugal installation, the working chamber of which performs complex angular oscillations and rotations around the inclined axis is shown in Fig.1 [3].

The working chamber 1 is hinged in the ring 2, which is fastened by bearings to the drive fork 3 . The fork 3 is rigidly connected to the hollow shaft 4 , which moves from the motor by the belt drive. Inside the hollow shaft 4 there is the shaft 5 of the crank mechanism 6 , which performs angular oscillations of the working chamber 1 .

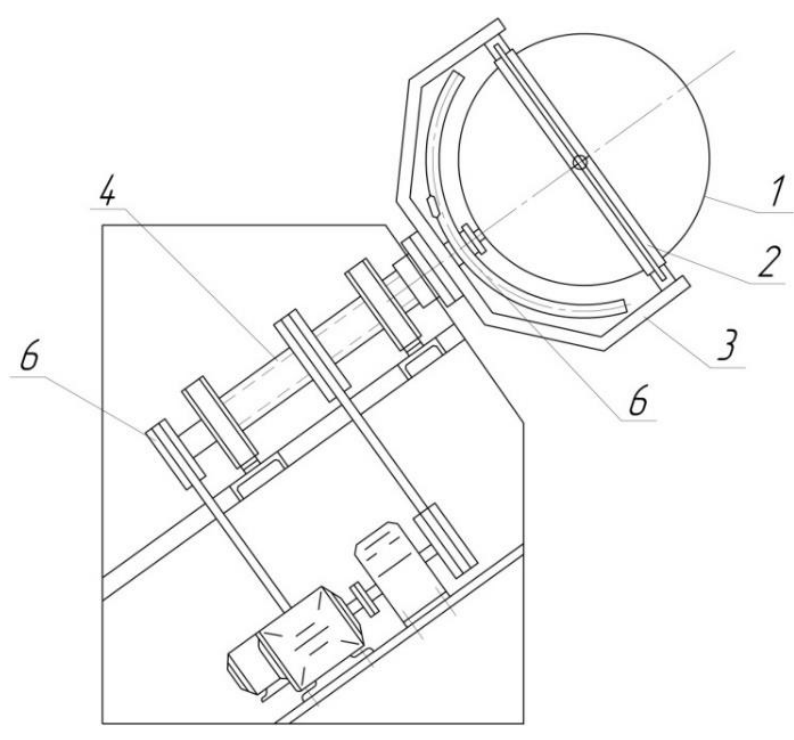

Figure 1. Scheme of vibration-centrifugal installation

Let us choose the fixed coordinate system Oxyz (Fig. 2), which is connected to the case of the vibration-centrifugal installation (VCI). The fork 1 rotates around the axis Oy at angle $\alpha$, the frame 2 around the axis $\mathrm{Oz}$ at angle $\beta$, and the chamber 3 around the axis Ox at angle $\gamma$.

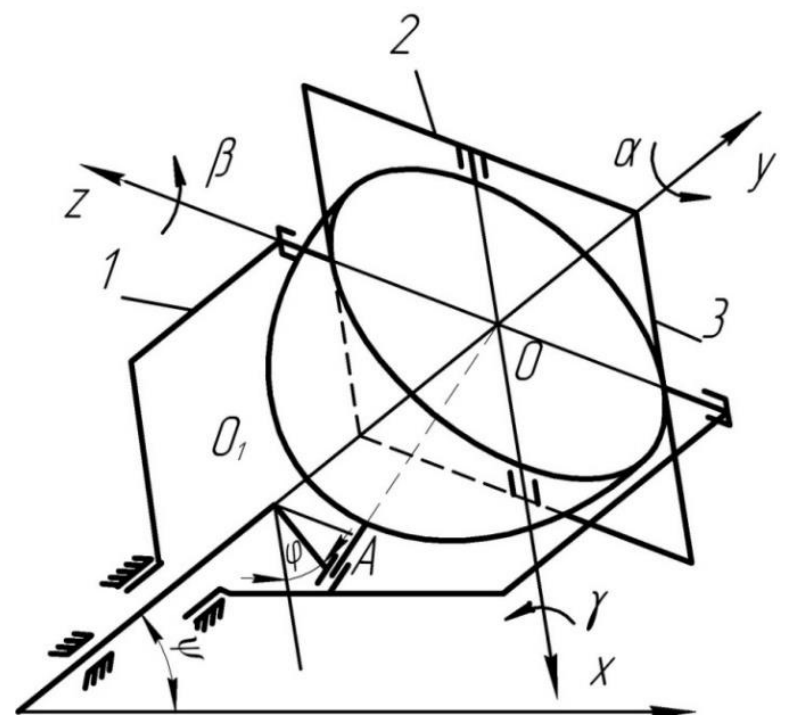

Figure 2. Kinematic scheme of vibration-centrifugal installation 
Let us connect the coordinate system $\mathrm{Ox}_{1} \mathrm{y}_{1} \mathrm{z}_{1}$ with the fork 1 with the frame $2 \mathrm{Ox}_{2} \mathrm{y}_{2} \mathrm{Z}_{2}$, with the camera $3 \mathrm{Ox}_{3} \mathrm{y}_{3} \mathrm{z}_{3}$. Since the fork 1 rotates around the axis Oy with constant angular velocity $\omega_{1}$, then $\alpha=\omega_{1} \cdot t$. The crank $\mathrm{O}_{1} \mathrm{~A}$ rotates around the axis $\mathrm{Oy}$ with constant angular velocity $\omega_{2}$, therefore $\varphi=\omega_{2} \cdot t$, then the angles $\beta$ and $\gamma$ are equal to: [2]

$$
\left\{\begin{array}{l}
\beta=\operatorname{arcrg} \frac{r \cdot \sin \varphi}{H} \\
\gamma=-\operatorname{arcrg} \frac{r \cdot \cos \varphi}{\sqrt{H^{2}+r^{2} \sin ^{2} \varphi}}
\end{array}\right.
$$

where $r$ is the crank radius, $H=O_{1} O$ is the distance between the origin of coordinates Oxyz and the plane of the crank rotation $\mathrm{O}_{1} \mathrm{~A}$.

Let us accept the ration of design parameters $\lambda=\frac{r}{H}$. According to the investigation [2], the value $\lambda \leq 0.25$ ensuring stable VCI operation with the amplitude of angular oscillations $\beta$ and $\gamma$ is not more than $15^{\circ}$. in Fig. 3.

The relative position of the bodies and the corresponding coordinate systems is shown

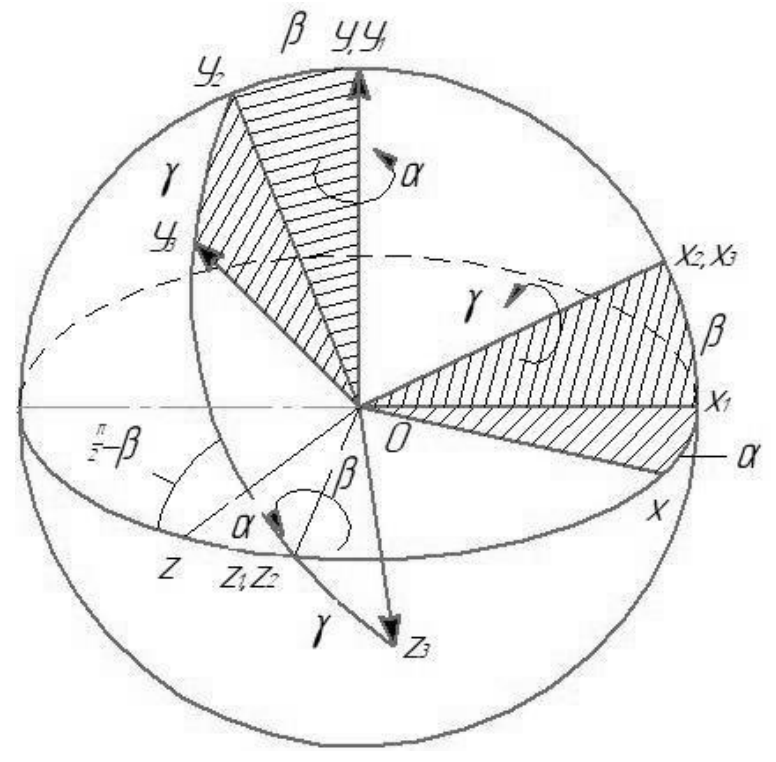

Figure 3. Diagram of chamber motion

The cardan suspension simulates Euler-Krylov angles. Let us calculate the table of guide cosines of the body by matrix method [4-5].

$$
\begin{gathered}
{[x, y, z]^{T}=\bar{B}_{1}\left[x_{1}, y_{1}, z_{1}\right]^{T},} \\
{\left[x_{1}, y_{1}, z_{1}\right]^{T}=\bar{B}_{2}\left[x_{2}, y_{2}, z_{2}\right]^{T},}
\end{gathered}
$$




$$
\begin{gathered}
{\left[x_{2}, y_{2}, z_{2}\right]^{T}=\bar{B}_{3}\left[x_{3}, y_{3}, z_{3}\right]^{T},} \\
{[x, y, z]^{T}=\bar{B}\left[x_{3}, y_{3}, z_{3}\right]^{T}}
\end{gathered}
$$

Here

$$
\begin{gathered}
\bar{B}_{1}=\left[\begin{array}{ccc}
\cos \alpha & 0 & \sin \alpha \\
0 & 1 & 0 \\
-\sin \alpha & 0 & \cos \alpha
\end{array}\right], \\
\bar{B}_{2}=\left[\begin{array}{ccc}
\cos \beta & -\sin \beta & 0 \\
\sin \beta & \cos \beta & 0 \\
0 & 0 & 1
\end{array}\right], \\
\bar{B}_{3}=\left[\begin{array}{ccc}
1 & 1 & 0 \\
0 & \cos \gamma & -\sin \gamma \\
0 & \sin \gamma & \cos \gamma
\end{array}\right]
\end{gathered}
$$

The resulting rotation matrix $\bar{B}$ is found as the product

$$
\begin{aligned}
& \bar{B}=\bar{B}_{1} \bar{B}_{2} \bar{B}_{3}= \\
& {\left[\begin{array}{ccc}
\cos \alpha \cos \beta & \sin \alpha \sin \gamma-\cos \alpha \cos \gamma \sin \beta & \sin \alpha \cos \gamma+\cos \alpha \sin \gamma \\
\sin \beta & \cos \beta \cos \gamma & -\cos \beta \sin \gamma \\
-\sin \beta \cos \beta & -\cos \alpha \sin \gamma+\sin \alpha \cos \gamma \sin \beta & \cos \alpha \cos \gamma-\sin \alpha \sin \gamma \sin \beta
\end{array}\right.}
\end{aligned}
$$

Therefore, the parametric equations of points of the inner chamber surface at any moment depending on the angles $\alpha, \beta i \gamma$ are as follows:

$$
\left\{\begin{array}{l}
x=x_{3} \cos \alpha \cos \beta+y_{3} \sin \beta-z_{3} \sin \alpha \cos \beta \\
y=x_{3}(\sin \alpha \sin \gamma-\cos \alpha \cos \gamma \sin \beta)+y_{3} \cos \beta \cos \gamma+z_{3}(\cos \alpha \sin \gamma+\sin \alpha \cos \gamma \sin \beta) \\
z=x_{3}(\sin \alpha \cos \gamma+\cos \alpha \sin \gamma \sin \beta)-y_{3} \cos \beta \sin \gamma+z_{3}(\cos \alpha \cos \gamma-\sin \alpha \sin \gamma \sin \beta)
\end{array}\right.
$$

Since $\beta_{\max }=\gamma_{\max }=15^{\circ}, \cos 15^{\circ}=0,966$, then with an error not exceeding $3,3 \%$ we can assume that $\cos \beta \approx 1, \cos \gamma \approx 1$.

Then equations (2) are as follows:

$$
\left\{\begin{array}{l}
x=x_{3} \cos \alpha+y_{3} \sin \beta-z_{3} \sin \alpha \\
y=x_{3}(\sin \alpha \sin \gamma-\cos \alpha \sin \beta)+y_{3}+z_{3}(\cos \alpha \sin \gamma+\sin \alpha \sin \beta) \\
z=x_{3}(\sin \alpha+\cos \alpha \sin \gamma \sin \beta)-y_{3} \sin \gamma+z_{3}(\cos \alpha-\sin \alpha \sin \gamma \sin \beta) .
\end{array}\right.
$$


Let us consider the case when the amplitudes of oscillations of the frame and the working chamber are within the range $3^{0} \ldots 6^{0}$, then we can assume that:

$$
\left\{\begin{array}{l}
\gamma=-\lambda \cos \omega_{2} t \\
\beta=\lambda \sin \omega_{2} t
\end{array}\right.
$$

By differentiating the left and right parts of the equations system (3) over time, we obtain the dependences of the velocity at any point $M$ with coordinates $\left(\mathrm{x}_{3} ; \mathrm{y}_{3} ; \mathrm{z}_{3}\right)$ on time.

$$
\left\{\begin{array}{l}
\dot{x}=-x_{3} \sin \alpha \cdot \dot{\alpha}+\dot{y}_{3} \cdot \dot{\beta}-z_{3} \cos \alpha \cdot \dot{\alpha} \\
\dot{y}=x_{3}(\cos \alpha \cdot \sin \gamma \cdot \dot{\alpha}+\sin \alpha \cdot \dot{\gamma}-\dot{\alpha} \sin \alpha \cdot \sin \beta+\dot{\beta} \cdot \cos \alpha)+z_{3}(-\dot{\alpha} \sin \alpha \cdot \sin \gamma+\dot{\gamma} \cos \alpha) \\
\dot{z}=x_{3}(\cos \alpha \cdot \dot{\alpha}-\sin \alpha \cdot \dot{\alpha} \cdot \sin \beta \cdot \sin \gamma+\cos \alpha(\dot{\beta} \cdot \sin \gamma+\dot{\gamma} \cdot \sin \beta))-y_{3} \cdot \dot{\gamma}+ \\
z_{3}(-\sin \alpha \cdot \dot{\alpha}-\cos \alpha \cdot \dot{\alpha} \cdot \sin \beta \cdot \sin \gamma+\sin \alpha(\dot{\beta} \cdot \sin \gamma+\dot{\gamma} \cdot \sin \beta))
\end{array}\right.
$$

where $\dot{\beta}=\lambda \cdot \omega_{2} \cdot \cos \varphi, \dot{\gamma}=\lambda \cdot \omega_{2} \cdot \sin \varphi$.

Let us consider the conditional equilibrium of the abrasive particle, which is located on the inner surface of the chamber. According to D'Alembert principle [5] we get:

$$
\vec{P}+\vec{N}+\vec{F}_{T}+\vec{\phi}=0
$$

where $\vec{P}$ is the gravity force, $\vec{N}$ is normal reaction of chamber surface, $\vec{F}_{T}$ is friction force, $\vec{\phi}$ is inertial force, $\vec{\phi}=-m \vec{a}$.

Let us draw through each point $M_{i}$ with coordinates $\left(x_{i}, y_{i}, z_{i}\right)$, the normal $(i=1 \ldots 12$ ) which vector has the following coordinates:

$$
X_{i}=-x_{i} ; Y_{i}=-y_{i} ; Z_{i}=-z_{i}
$$

Projecting equation (7) to the normal we obtain:

$$
N=P_{n}+\phi_{n}, \text { where } \vec{P}=m \vec{g}, N^{\prime}=\frac{N}{m}=g_{n}+a_{n}
$$

The coordinates of gravitational acceleration vector are as follows:

$$
g_{x}=-g \cos \psi ; g_{y}=g \sin \psi, g_{z}=0
$$

where $\psi$ is the inclination angle of axis Oy to the horizon.

Knowing the projections of acceleration point $M_{i}$ on the coordinate axes $a_{x i}, a_{y i}, a_{z i}$, we can determine the value $N^{\prime}$. 


$$
N^{\prime}=\frac{\left(g_{x}+a_{x i}\right) X_{i}+\left(g_{y}+a_{y i}\right) Y_{i}+\left(g_{z}+a_{z i}\right) Z_{i}}{\sqrt{X_{i}^{2}+Y_{i}^{2}+Z_{i}^{2}}}
$$

Let us determine the kinetic energy of the abrasive particle, which is at point $M_{i}$ at the moments when the separation of abrasive particle from the chamber occurs $N^{\prime}>0$.

$$
E_{k}=\frac{m V_{i}^{2}}{2}=\frac{m\left(V_{x i}^{2}+V_{y i}^{2}+V_{z i}^{2}\right)}{2}
$$

where $V_{x i}, V_{y i}, V_{z i}$ are projections of the velocity of point $M_{i}$ on the coordinate axis at time moment $t_{k}$.

Then the kinetic energy given by the camera to the abrasive particles at the point $M_{i}$ over time $t_{1}$ is equal to:

$$
T_{i}=\sum_{k=1}^{t_{1}} E_{k}
$$

The kinetic energy that the abrasive particles receives from the entire chamber over time $t_{1}$ is:

$$
T=\sum_{i=1}^{80} T_{i}
$$

The value $t_{1}$ is determined from the condition that during this time the working chamber makes the complete number of revolutions around the axis Oy.

$$
t_{1}=\frac{60}{\Delta n_{1}}
$$

where $\Delta n_{1}$ is the step of changing the speed of camera rotation around the axis Oy.

Then we determine the kinetic energy given by the camera to abrasive particles of the unit mass over time $t_{1}$.

$$
T^{\prime}=\frac{T}{m \cdot t_{1}}
$$

The response surface of the specific kinetic energy dependence $T$ on the rotation velocity of the fork $n_{1}$ and the crank $n_{2}$ is shown in Fig. 4. 


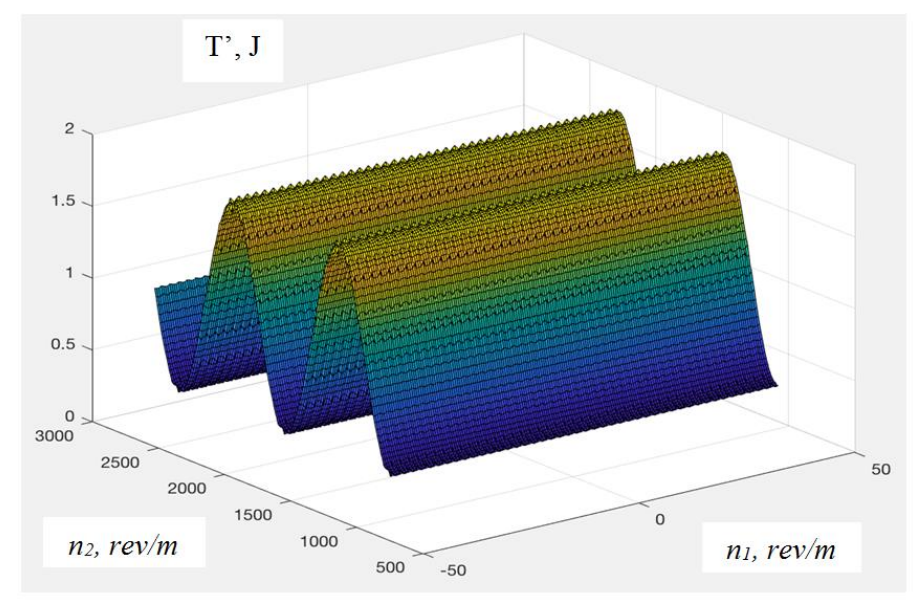

Figure 4. The response surface of the specific kinetic energy dependence $T^{\prime}$ on the rotation velocity of the fork $n_{1}$ and the crank $n_{2}$

The dependences of specific kinetic energy $T$ ' on the crank rotation velocity at different values of the fork rotation velocity are presented in Fig. 5-7.

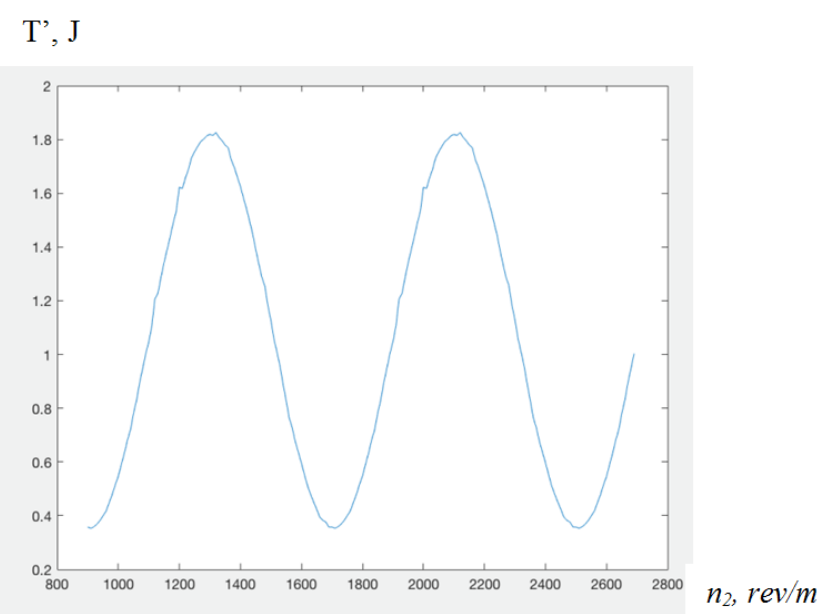

Figure 5. Dependences of specific kinetic energy $T^{\prime}$ on the crank rotation velocity $\left(n_{1}=-30 \mathrm{rev} / \mathrm{m}\right)$

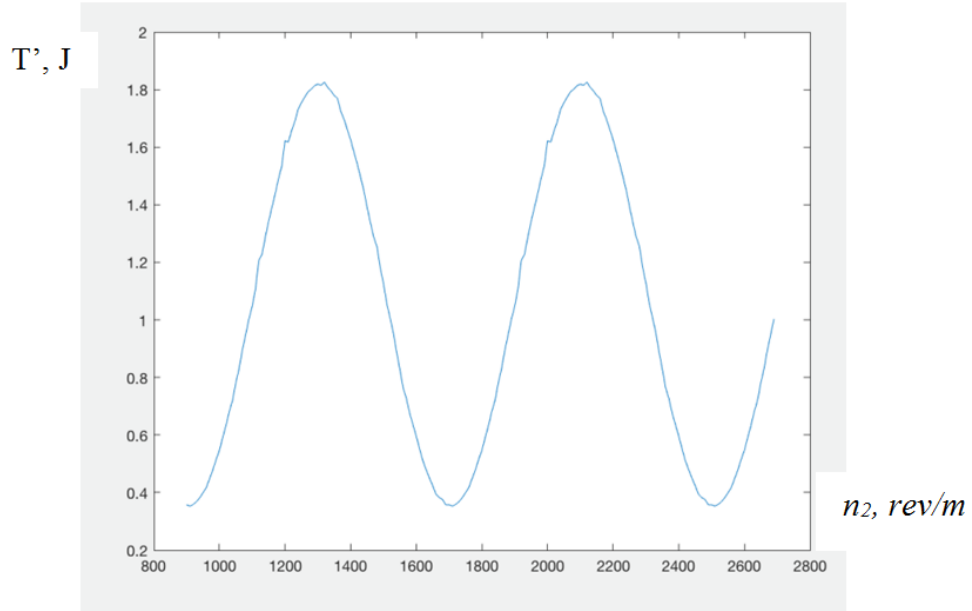

Figure 6. Dependences of specific kinetic energy $T^{\prime}$ on the crank rotation velocity $\left(n_{1}=0 \mathrm{rev} / \mathrm{m}\right)$ 


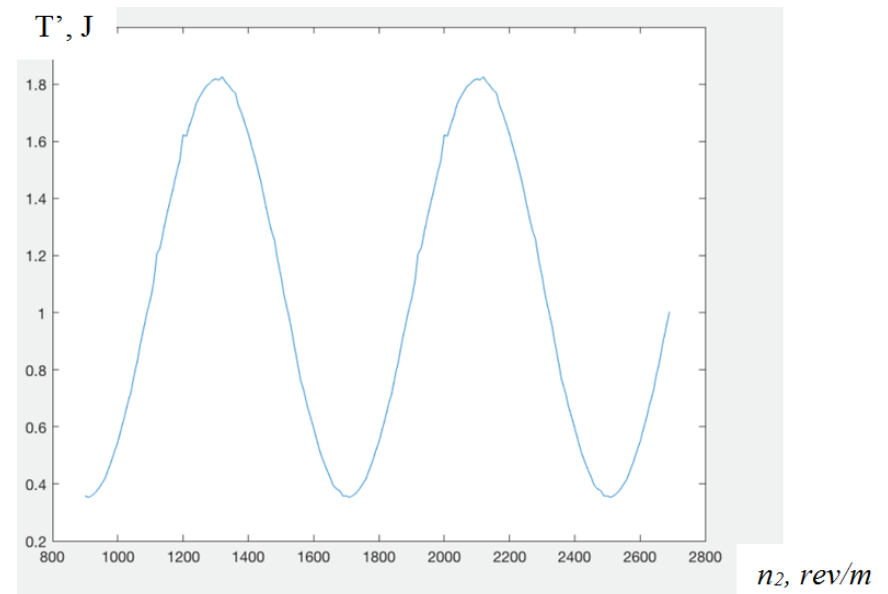

Figure 7. Dependences of specific kinetic energy $T^{\prime}$ on the crank rotation velocity $\left(n_{1}=30 \mathrm{rev} / \mathrm{m}\right)$

The dependences of specific kinetic energy on the fork rotation speed at different values of the crank rotation velocity are presented in Fig. 8-10.

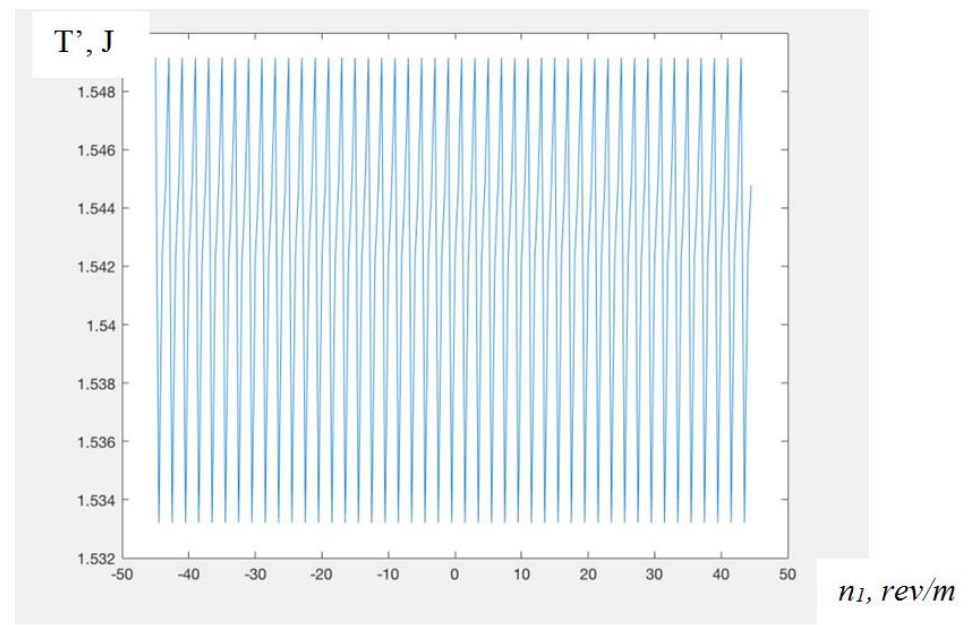

Figure 8. Dependences of specific kinetic energy $T^{\prime}$ on the fork rotation velocity $\left(n_{2}=1200 \mathrm{rev} / \mathrm{m}\right)$

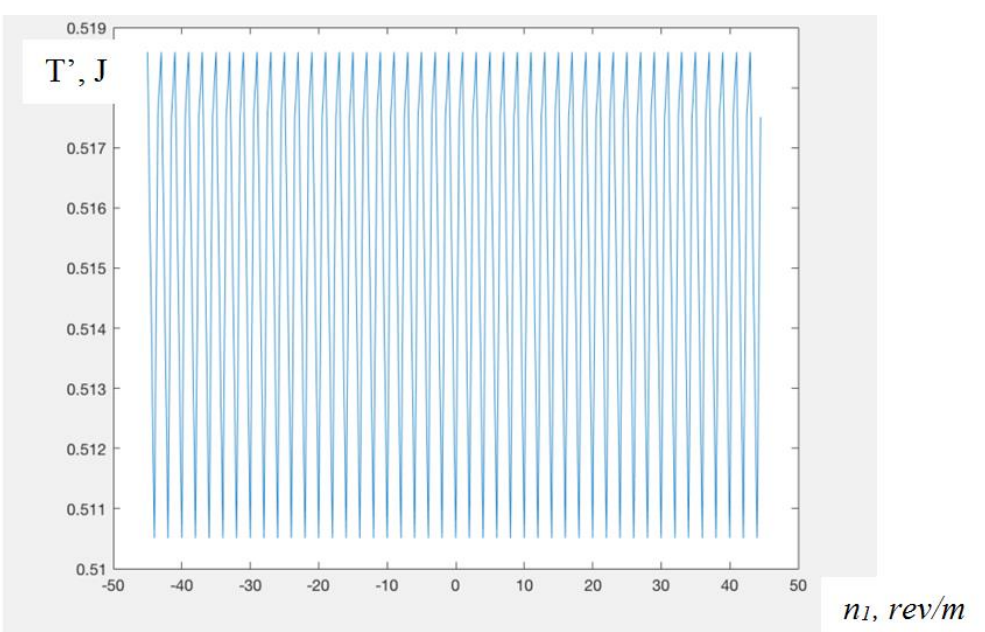

Figure 9. Dependences of specific kinetic energy $T^{\prime}$ on the fork rotation velocity $\left(n_{2}=1800 \mathrm{rev} / \mathrm{m}\right)$ 


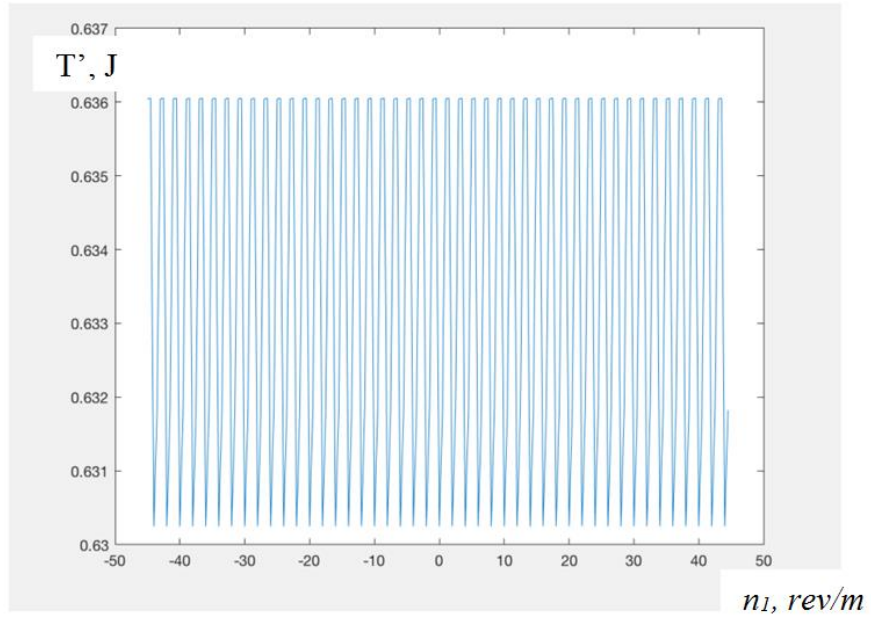

Figure 10. Dependences of specific kinetic energy on the fork rotation velocity $\left(n_{2}=2400 \mathrm{rev} / \mathrm{m}\right)$

Conclusion. The carried out analysis makes it possible to expand the opportunities and to optimize parameters of machine parts vibration-centrifugal treatment in loose abrasive environment. It is determined that the greater is the kinetic energy provided by the chamber to the abrasive particles, the greater is the work spent on the parts finishing. Therefore, knowing the parameters of vibration-centrifugal installation, we can choose rational values of angular velocities for the fork and the crank, providing necessary machine parts finish.

\section{References}

1. Babichev A. P., Trunin V. B., Samodumskii Yu. M., Ustinov V. P. Vibratsionnye stanki dlya obrabotki detalei [Vibrating Machines for Parts Processing]. Moscow: Mashinostroenie, 1984. 168 p.

2. Kondratjuk O. M., Romejko I. V. Analiz cyrkuljaciji robochogho seredovyshha pry vibracijno-vidcentrovij obrobci detalej [Analysis of the circulation of the working medium during vibration-centrifugal machining of parts]. Visnyk NUVGhP. Vypusk 2 (3). Rivne: 2006. P. 253-271.

3. Pat. 109854 Ukrajina, MPK V24 V31/6. Vibracijno-vidcentrova ustanovka. [Vibrating and centrifugal installation] / Kondratjuk O. M., Ghalan Ju. A., Ljashuk O. L., Skyba O. P.; zajavnyk ta patentovlasnyk: Kondratjuk O. M., Ghalan Ju. A., Ljashuk O. L., Skyba O. P.; u 2016 02643; zajavl. 17.03.2016; opubl. 12.09.2016, Bjul. № 17.

4. Serilko L. S., Kondratjuk O. M. Analiz vyznachennja syly rizannja i znjattja metalu pry obrobci detalej v abrazyvnomu seredovyshhi vibracijno-vidcentrovogho stanka [Analysis of the determination of the cutting force and metal removal when processing parts in an abrasive environment of a vibration-centrifugal machine] Vseukrajinsjkyj naukovo-tekhnichnyj zhurnal "Vibraciji v tekhnici ta tekhnologhijakh". Vypusk № 2 (47)/ 2007. P. 64-69.

5. Pavlovsjkyj M. A. Teoretychna mekhanika: pidruchnyk. K.: Tekhnika, 2002. 512 p.

6. URL: ttps://uk.wikipedia.org/wiki/\%D0\%86\%D0\%BA\%D0\%BE\%D1\%81\%D0\%B0\%D0\%B5\%D0\%B4 $\% \mathrm{D} 1 \% 80$.

7. Alexander Kondratyuk, Oleg Ljasuk, Volodymyr Klen Action, Yuriy Galan Investigation of the interaction of abrasive working medium particle in vibration treatment with machined parts of surfaces. Bulletin of the Ternopil National Technical University. Scientific Journal of the Ternopil National Technical University. 2017. No. 2 (86). P. 32-40.

8. Kondratiuk O., Teslia V., Kuchvara I., Bosiuk P., Galan Yu. Theoretical substantiation of vibrationcentrifugal finishing of parts by loose abrasives. MOTROL. Commission of Motorization and Energetics in Agriculture. Lublin-Rzeszów, 2018. Vol. 20. No. 1. P. 73-78.

9. Pshenychnыj Y. N. Rasshyrenye tekhnologhycheskykh vozmozhnostej obrabotky detalej V vybryrujushhykh kontejnerakh [Expansion of technological capabilities for processing parts in vibrating containers]: dys. ... kand. tekh. nauk: 05.03.01. Lughansk, 2004. 265 p.

\section{Список використаної літератури}

1. Бабичев А. П. Основы вибрационной технологии. Ростов-н/Д.: Издательский центр ДГТУ, 2008. $694 \mathrm{c}$. 
2. Кондратюк О. М., Ромейко І. В. Аналіз циркуляції робочого середовища при вібраційновідцентровій обробці деталей. Вісник НУВГП. Випуск 2 (3). 2006. С. 253-271.

3. Вібраційно-відцентрова установка: пат. 109854 Україна, МПК В24 В31/6. заявл. 17.03.2016; опубл. 12.09.2016, Бюл. № 17.

4. Серілко Л. С., Кондратюк О. М. Аналіз визначення сили різання і зняття металу при обробці деталей в абразивному середовищі вібраційно-відцентрового станка. Всеукраїнський науковотехнічний журнал «Вібрації в техніці та технологіях». Випуск № 2 (47). 2007. С. 64-69.

5. Павловський М. А. Теоретична механіка: підручник. К.: Техніка, 2002 р. 512 с.

6. URL: ttps://uk.wikipedia.org/wiki/\%D0\%86\%D0\%BA\%D0\%BE\%D1\%81\%D0\%B0\%D0\%B5\%D0\%B4 $\% \mathrm{D} 1 \% 80$.

7. Kondratyuk A., Lyashuk O., Klendiy V., Galan Yu. Investigation of the interaction of abrasive working medium particle in vibration treatment with machined parts of surfaces. Bulletin of the TNTU: Sciences. same. TNTU. 2017. Vip. 2 (86). P. 32-40.

8. Kondratiuk O., Teslia V., Kuchvara I., Bosiuk P., Galan Yu. Theoretical substantiation of vibrationcentrifugal finishing of parts by loose abrasives. MOTROL. Commission of Motorization and Energetics in Agriculture. 2018. Vol. 20. No. 1. P. 73-78. LUBLIN -RZESZÓW 2018.

9. Пшеничный И. Н. Расширение технологических возможностей обработки деталей в вибрирующих контейнерах: дис. ... канд. тех. наук: 05.03.01. Луганск, 2004. 265 с.

\title{
УДК 621.9.048
}

\section{ДОСЛІДЖЕННЯ РОБОТИ ВІБРАЦІЙНО-ВІДЦЕНТРОВОЇ УСТАНОВКИ ДЛЯ ОБРОБКИ ДЕТАЛЕЙ АВТОМОБІЛІВ}

\section{Олег Ляшук ${ }^{1}$ Леонід Серілко²; Іван Гевко; Олександр Кондратюк²; Олег Цьонь ${ }^{1}$; Юрій Галан ${ }^{1}$}

\author{
${ }^{1}$ Тернопільський національний технічний університет імені Івана Пулюя, \\ Тернопіль, Україна \\ ${ }^{2}$ Національний університет водного господарства та \\ природокористування, Рівне, Україна
}

\begin{abstract}
Резюме. Наведено схему вібрачійно-відиентрової установки, яка забезпечує підвищення продуктивності й ефективності вібраиійної обробки деталей. Вібраиійно-відцентрова установка здійснює обробку з просторовим чи планетарним рухом робочої камери, але і в установках з рухом робочої камери по складній просторовій кривій. Дана вібраційно-відчентрова установка, робоча камера якої розміщена в середині карданного підвісу, й здійснює складні кутові коливання. Даний технологічний прочес вібраційної обробки деталей в сипучому абразивному середовищі підвищує ї̈ інтенсивність в 2 ...2,5 раза. На основі математичного моделювання дослідженню питання впливу оброблюваного середовища на технологічний процес вібраційного оброблення та визначення його оптимальних параметрів. Отримано параметричні рівняння внутрішньої поверхні камери в будь-який момент часу залежно від кутів $\alpha, \quad \beta \quad i \quad \gamma$

оброблювального середовища - базових параметрів, які характеризують інтенсивність процесу віброоброблення. Представлено залежність кінетичної енергії, щзо отримують частинки абразиву від всієі камери за час $t_{1}$. Побудована на основі принципу Д'Аламбера модель руху сипкого середовища вібраційновідиентрової установки, в якій представлено як суцільне та однорідне у вигляді натарування плоских пружно-пластичних балок, товщина яких значно мениа їх ширини. Взаємодія середовища із вібраційновідчентрової установки описується жорсткою та пружною моделями контакту. На основі результатів досліджень визначено, що величина стаціонарного значення амплітуди коливань шару середовища не залежить від початкових умов і у кожному випадку прямує до свого певного значення, яке визначається параметрами середовища. Представлено графічні залежності питомої кінетичної енергї від частоти обертання кривошипа при різних значеннях частоти обертання вилки. Визначено ефективні шляхи оптимізації параметрів технологічного процесу та нових иляхів його розвитку.

Ключові слова: вібраційна обробка, технологічний процес, абразивна гранула, швидкість гранули, кінетична енергія.
\end{abstract}

